\title{
Living at a High Arctic Polynya: Inughuit Settlement and Subsistence around the North Water during the Thule Station Period, 1910-53
}

\author{
Bjarne Grønnow ${ }^{1}$
}

\author{
(Received 19 February 2016; accepted in revised form 12 April 2016)
}

\begin{abstract}
The settlement and subsistence patterns of the Inughuit of the Avanersuaq (Thule area) are described and analyzed for the years 1910 to 1953, when Knud Rasmussen's trading station at Dundas was active. Inughuit subsistence was based on the rich biotic resources of the North Water polynya between Ellesmere Island and Greenland, but the analysis shows that trade, primarily with fox furs at the Thule Station, also played a major role in shaping the settlement pattern of the period. During the Thule Station Period, the named winter settlements amounted to c. 40 sites; however, only $10-15$ of them were settled at any given time. The Inughuit settlement close to the station, Uummannaq, soon became the largest site in the area. The sources enable us to follow changes of residence of some hunting families over four decades. By moving their winter sites every second or third year, the families gained primary knowledge of the topography and seasonal variation of the hunting grounds in the entire Thule district during their active years. In the same way, they connected with diverse family networks through the years. Tracing the sledge routes that connected the sites over great distances reveals how decisive proximity to main and escape routes over the Ice Cap was for site location. Dog sledge technology, and thus capacity to transport people, gear, and stored food, boomed during the Thule Station Period with the wealth created from trade and access to raw materials. Mapping the main hunting grounds on the sea ice and modeling the hunters' annual range of possibilities for accessing different game - mainly walrus, ringed seal, narwhal, and sea birds (plus some caribou) — showed that ringed seal formed the bread and butter of the subsistence economy. However, bulk resources, gained in particular from intensive spring walrus hunts at a few hot spots, as well as carefully timed consumption and sharing of the stored meat and blubber, were keys to life at the North Water polynya. Temporary settlement at the trading stations in the area - a couple of winters at a time - was also part of the risk management strategy of the Inughuit.
\end{abstract}

Key words: historic Inughuit; North Water polynya; subsistence/settlement patterns; hunting strategies; hunting grounds; annual hunting cycle; sledge routes; trade

RÉSUMÉ. Les modèles d'établissement et de subsistance des Inughuits de l'Avanersuaq (région de Thulé) font l'objet de descriptions et d'analyses pour les années allant de 1910 à 1953, à l'époque où la station de traite de Knud Rasmussen à Dundas était active. La subsistance des Inughuits reposait sur les riches ressources biotiques de la polynie des eaux du Nord, entre l'île d'Ellesmere et le Groenland, mais l'analyse montre que la traite, principalement celle de fourrure de renard à la station de Thulé, a également joué un grand rôle dans la formation du modèle d'établissement pendant cette période. Durant la période de la station de Thulé, le nombre d'établissements hivernaux nommés se chiffrait à environ 40 sites. Cependant, seulement 10 à 15 d'entre eux étaient fonctionnels en même temps. L'établissement des Inughuits près de la station, soit Uummannaq, a tôt fait de devenir le plus grand site de la région. Les sources nous permettent de suivre les changements de résidence de certaines familles de chasseurs sur quatre décennies. En déplaçant leurs sites hivernaux aux deux ou trois ans, les familles acquéraient des connaissances directes de la topographie et de la variation saisonnière des territoires de chasse de l'ensemble du district de Thulé pendant leurs années d'activité. De la même manière, ils entraient en contact avec divers réseaux familiaux au fil des ans. Le fait de retracer les chemins empruntés par les traîneaux qui reliaient les sites sur de grandes distances révèle à quel point la proximité des chemins principaux et des chemins d'évasion sur la calotte glaciaire jouait un grand rôle dans l'emplacement du site. La technologie des traîneaux à chiens et, par conséquent, la capacité à transporter des humains, de l'outillage et des vivres conservées, a battu son plein pendant la période de la station de Thulé, lorsque la richesse découlait de la traite et de l'accès aux matériaux bruts. Le mappage des principaux territoires de chasse sur la glace de mer et la modélisation de l'étendue annuelle des possibilités des chasseurs d'avoir accès à différents types de gibier — principalement le morse, le phoque annelé, le narval et les oiseaux marins (en plus d'un peu de caribou) - a permis de démontrer que le phoque annelé constituait l'essentiel des moyens d'existence de l'économie de subsistance. Cependant, les ressources en vrac, acquises par le biais de chasses printanières intensives du morse dans quelques points chauds, de même que la consommation et le partage soigneusement planifiés de la viande et du petit lard emmagasinés, étaient essentiels à la vie dans la polynie des eaux du Nord. L'établissement temporaire aux stations de traite de la région, environ deux hivers à la fois, faisait également partie de la stratégie de gestion des risques des Inughuits.

${ }^{1}$ SILA - The Arctic Centre at the Ethnographic Collections, Modern History and World Cultures, The National Museum of

Denmark, Frederiksholms Kanal 12, DK-1220 Copenhagen, Denmark; Bjarne.Gronnow@natmus.dk

(C) The Arctic Institute of North America 
Mots clés : Inughuit historique; polynie des eaux du Nord; modèles de subsistance et d'établissement; territoires de chasse; cycle de chasse annuel; chemins empruntés par les traîneaux; traite

Traduit pour la revue Arctic par Nicole Giguère.

\section{INTRODUCTION}

High Arctic recurrent polynyas are rare and separated by vast distances and areas of sea ice, but these Arctic oases, which offer an abundance of marine game and other resources (e.g., Vibe, 1950; Born and Böcher, 2001; HeideJørgensen et al., 2016), have always been crucial to humans in the High Arctic (Schledermann, 1980; Born, 1987). In recent decades, studies of pre-Inuit and Thule culture settlement and subsistence around polynyas have been carried out in Greenland through interdisciplinary research initiatives involving geography, biology, anthropology, and archaeology. With a starting point in work by Andreasen and Elling (1991) around the North East Water polynya (the NEWLand Project) and by the Sandells at the Scoresby Sund polynya (Sandell and Sandell, 1991), the GeoArk Project conducted archaeological and climatological investigations in the Sirius Water, a recurrent polynya in North East Greenland (2004-10). These campaigns highlighted the polynyas as stepping stones for various mobile prehistoric societies that populated North East Greenland (Gotfredsen, 2010; Grønnow, 2010; Sørensen, 2010).

The results and experiences from these investigations recently led to a renewed interest in settlement and subsistence around the important North Water polynya. Covering the northern Baffin Bay and Smith Sound between Avanersuaq (the Thule district) and Ellesmere Island (Fig. 1), the North Water has rich biotic resources that have attracted humans through four millennia. This gateway to Greenland (Appelt and Gulløv, 1999) has a complex cultural history that led to the present Inughuit settlement (Schledermann, 1990; Grønnow and Sørensen, 2006). Thus, the North Water, in contrast to the other polynyas in High Arctic Greenland, is connected to rich ethnohistoric material. The North Water Project (NOW), motivated by recent drastic changes in the living conditions of the Inughuit, brings archaeologists together with biologists and anthropologists in order to explore relations between humans and their biotic resources over the long term (Hastrup et al., 2015).

This paper provides a historical frame of reference for research within the NOW Project. It deals with Inughuit settlement and subsistence around the North Water during the relatively short Thule Station Period (TSP), the four decades between 1910 and 1953 when the trading post Kap York Stationen Thule, founded by Knud Rasmussen, was active (Hastrup, 2015:342). The ethnographic sources are particularly informative, and they make it possible to describe the geographical location and character of the historic Inughuit winter settlements, the communication and transportation networks that linked them, the mobility of the hunting families, the location of the main hunting grounds, seasonal hunting and trade possibilities, and hunting strategies.

Primary ethnographies of the TSP are Rasmussen (1921), Holtved (1944), and Vibe (1950), which are supplemented by the unpublished diaries of Holtved, 1935-37, and Gilberg's (1971) compilation.

\section{THE NETWORK}

During the TSP, the network of settlements in the Avanersuaq (Thule) area was probably more complex and widespread than ever (Fig. 2). The number of winter sites during the period covered by published population statistics (1923-35) was about 36, all of them with place names (Table 1) (Holtved, 1944:7-14; Gilberg, 1971). Some sites, for example Uummannaq, Neqi, and Kiatak, were almost continuously inhabited throughout the TSP. However, the combinations of households (or families; see Holtved, 1967:145; Gilberg, 1994:39) at these sites changed constantly. Most winter sites, like Sukat and Natsivilik, were settled only sporadically, but every site in the network was well known and could easily be occupied if a family decided to settle there. All winter sites had house ruins ready to move into following repair and rebuilding with turf and flagstones left by earlier inhabitants (Rasmussen, 1921:537). Likewise, caches for meat, blubber, and gear were reused, as well as fox traps and hare fences.

According to population statistics for 1923 to 1935 (Holtved, 1944:12), typically $10-15$ sites (i.e., $25 \%-40 \%$ of the potential winter sites) were settled at any given time. The total population numbered 250-270 individuals or about 60 households (Gilberg, 1976). The maps (Fig. 3) show active sites (and sizes) for three selected winters. Figure 3 and Table 1 demonstrate that the network of winter sites a) covered the entire region; b) showed great variation from year to year; c) included some sites that were continuously settled; d) included short-lived, "pioneer settlements" founded in the periphery (Inglefield Land and Melville Bugt); and e) consisted on average of four households per site (range $=1$ to 11), except for the Uummannaq site at the Thule Station, which included on average 11 households (range $=3$ to 15 ).

The sources are not informative concerning spring, summer, and fall sites. However, they describe some spring sites (e.g., Neqi) where several families gathered for new ice hunting of walrus, as well as fall sites for hunting caribou (Rangifer tarandus) in Inglefield Land. Summer tents were often erected at the same sites as the winter dwellings or next to bird colonies (Holtved, 1967:28-30). Initial archaeological surveys in the area by the NOW team in 2014 (Grønnow et al., 2015) have supplemented this picture. 


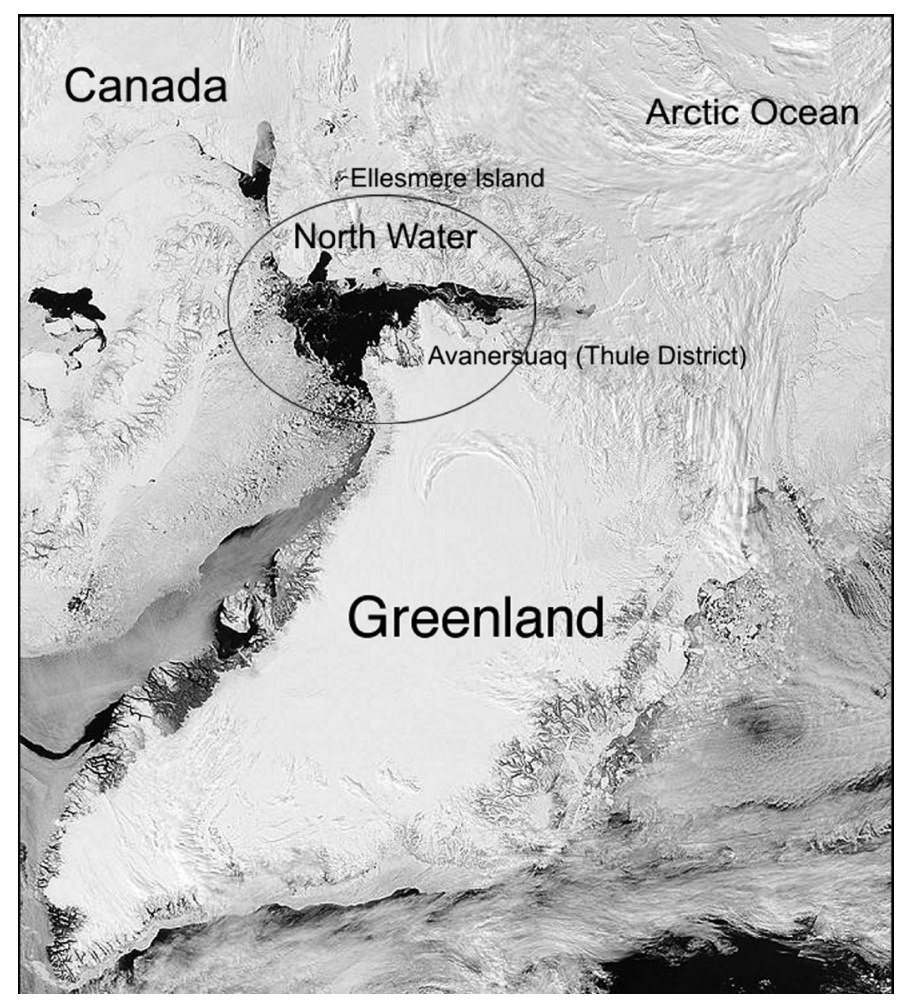

FIG. 1. The position of the North Water. Satellite image, with additions. (Courtesy: NASA/GSFC MODIS, 2003).

\section{INDIVIDUAL FAMILY MOBILITY}

Though some winter settlements look quite constant in size, as mentioned above, they vary considerably with regard to household composition. Thule population statistics reveal that individual families rarely used the same winter site for more than two consecutive years. They record the moves of seven individual households (as represented by the hunter) between winter settlements over a 12-year period from 1923 to 1935. Informative cases are Odaaq (one of Peary's Inughuit travel companions from 1909) and his son Kutsikitsoq. Based on compilations by Holtved (1944:13 - 14) and Gilberg (1971), Figure 4 shows the movements of these two closely related families between winter sites over a period of almost five decades (1936 to 1970). Other examples, for instance the Qalaseq and Inukitsupaluk families, confirm that frequent moves of winter residence were common (Holtved, 1944:13).

Rasmussen (1921:538) originally divided the Inughuit into four traditional population groups (from south to north): Nigerliit, Akunnaarmiut, Oqqorliit, and Avannaarliit. The high mobility among Inughuit during the TSP dissolved Rasmussen's sub-groups. However, their names are still useful as designations of geographical regions in Avanersuaq. The data show that the son, Kutsikitsoq, often settled with his father, Odaaq, even if he and his family, as typical for a household led by a young hunter, traveled more frequently and farther than his father did. Generally, the inhabitants of the small winter settlements were related through kinship, adoptive children, and sharing of resources. As exemplified by Odaaq, elderly hunters and their households tended to cease their nomadic life, first by staying more frequently with the son's family and finally by settling permanently at safe havens near trade posts, like Ummannaq, Siorapaluk, Savissivik and, ultimately, Qaanaaq (Gilberg, 1971:57). The end of the TSP was marked by the unfortunate forcible removal of the inhabitants from Uummannaq as a consequence of the establishment of the Thule Air Base, and Qaanaaq became the administrative center where wooden houses were built (Hastrup, 2015:382). Odaaq and Kutsikitsoq exemplify this drastic change, as both father and son settled (for winters at least) in Qaanaaq from 1953 onwards.

\section{INFRASTRUCTURE: THE HEYDAY OF THE DOG SLEDGE}

The annual formation of fast ice and the intensive use of dog sledge transportation must be emphasized as shaping the settlement pattern during the TSP. This period saw the peak of dog sledge technology, which facilitated transportation of people and heavy loads. Before European contact, and to a certain degree well into the late 19th century, access to wood was extremely limited. As described by Ross (1819), Inughuit sledges were built from pieces of bone, ivory, and antler lashed together. Wood appeared only as a symbolic component of the construction. The sledges were remarkably small and pulled by few dogs (Astrup, 1895:95; Rasmussen, 1921:558). Following contact, industrial wood was purchased from European whalers, though still in limited quantities, as seen from the illustrations in the ethnographic sketch of Bessels (1884:868). This situation changed with the large-scale American expeditions from the 1890s until 1909 (Astrup, 1895; Peary, 1898). Finally, the establishment of the Thule Station in 1910 meant stable supplies of high-quality boards and other materials and an increasing need for transportation of gear and supplies. The rise in purchasing power of the hunters was accelerated by the fox fur trade, and thus they had the means, as well as the motivation, to build larger and larger dog sledges (Fig. 5). Increasing amounts of meat and blubber were invested in teams of up to 15 dogs (Holtved, 1967:61 - 74), and the sledges developed into transportation machines capable of pulling loads of 1600 pounds (Rasmussen, 1921:558).

Thus, the possibilities increased of moving entire families over long distances, making long-distance hunting trips, and transporting large quantities of meat and blubber from the hunting grounds and between caches and settlements. Even though winter sites were far from each other, they were nevertheless connected by the dense network of sledge routes (Fig. 6). The network was shaped by the position of glaciers leading to the plain of the Ice Cap and by the character of the sea ice of the North Water. Open water areas driven by wind and sea currents, unstable ice, ice ledges, iceberg banks, and thick snow cover formed 


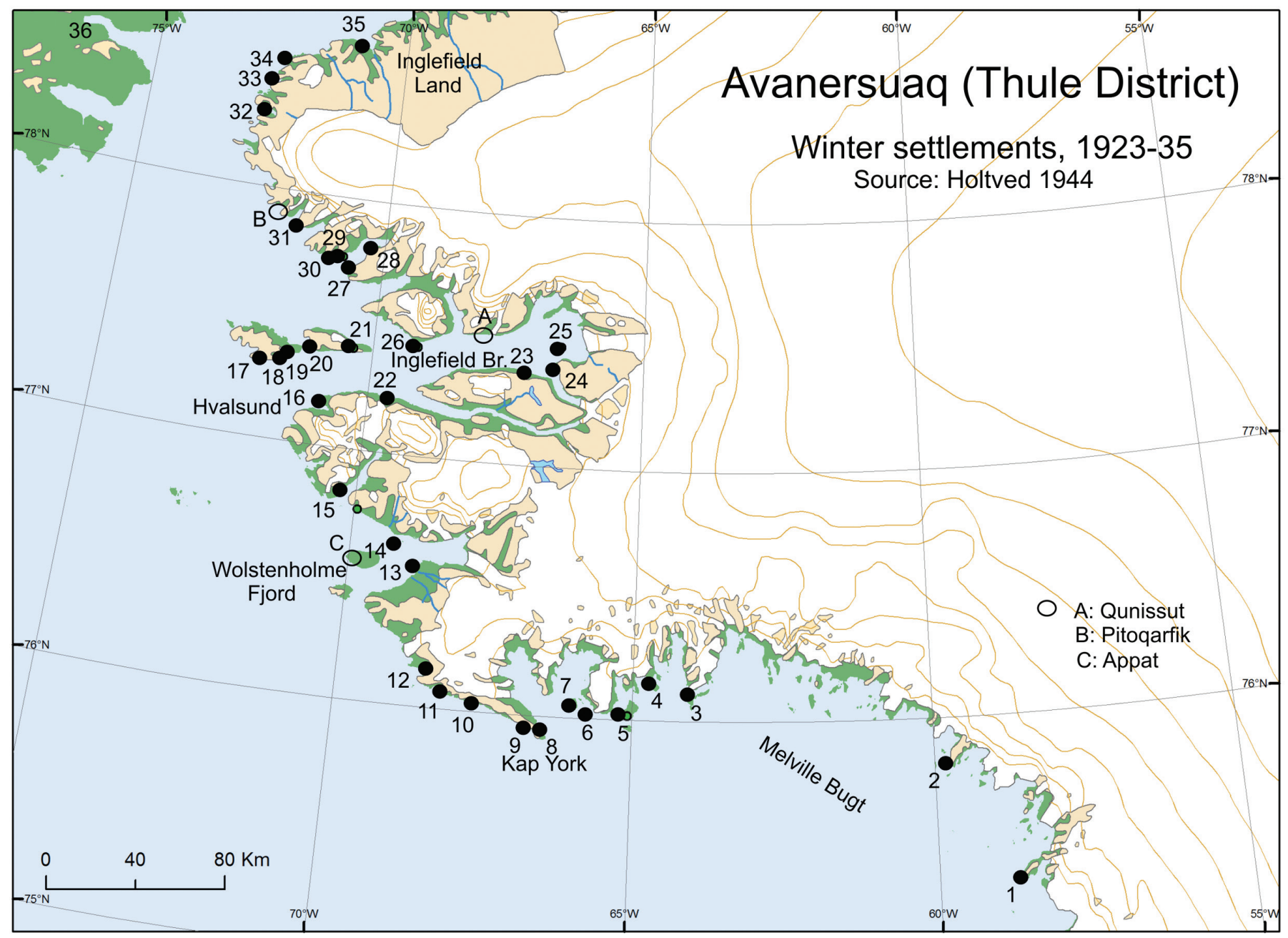

FIG. 2. Winter settlements in Avanersuaq, 1923-35. Settlement place names are given in Table 1.

obstacles to sledge driving in the polynya area (Vibe, 1950:12-13). Furthermore, sledging on the sea ice along some of the promontories (e.g., Kap Alexander) or glacier fronts was often impossible, or at least quite risky, and consequently, routes over the Ice Cap behind unreliable ice were often preferred. It could be fatal to be isolated from other groups during breakup with no emergency exit via the Ice Cap or the ice foot along the coast (Gilberg, 1971:55).

\section{AGGREGATION SITES AND PIONEERS}

A few Inughuit settlements functioned as aggregation camps. Neqi, Pitoqarfik, and Appat were starting points of important spring walrus hunts on new ice (smooth and transparent) and at the fast ice edge. Once a year, the majority of the Inughuit gathered for several weeks at these focal sites to conduct coordinated walrus hunts and thereby fill the caches (Astrup, 1895:104-119; Rasmussen, 1921:559; Vibe, 1950:28). Moreover, Uummannaq at the Thule Station and the trading posts, Siorapaluk (founded 1929) in the north and Savissivik (founded 1934) in the south, can be designated as aggregation sites in the sense that the trade and relative food security that they offered attracted several families and made them settle at these sites several times during the TSP, but for only two years or less each time. The majority of the winter sites in the district consisted of small settlements (one to five households), situated in all parts of the district. This pattern was dependent on effective communication and reliable transport of heavy loads of both people and resources between the dispersed settlements. The developed dog sledge complex was the technological means by which such a flexible settlement strategy was maintained. It meant that hunters gained primary knowledge of the topography and dynamics of both landscape and seascape in the entire Avanersuaq area, as well as experience using all the resources of the district. In this way, the families' social landscape came to encompass practically all members of Inughuit society.

The settlement history during the TSP shows that the founding of pioneer sites was an integral part of the strategy. Odaaq established his winter site on Nuussuaq in 1933 far southeast in the Melville Bugt, and he was probably driven by a desire to test new hunting grounds. Odaaq and a number of his fellow Inughuit were renowned in both the local community and among Euro-American explorers as 
TABLE 1. Population statistics for the settlements of Avanersuaq (Thule area) from 1923 to 1935 (population numbers and old orthography from Holtved, 1944). The number of households (H) and inhabitants (I) is given for each year. No data are available for 1928 and 1932.

\begin{tabular}{|c|c|c|c|c|c|c|c|c|c|c|c|c|c|c|c|c|c|c|c|c|c|c|c|c|c|}
\hline \multirow[b]{2}{*}{ No. } & \multirow[b]{2}{*}{ Old orthography } & \multirow[b]{2}{*}{ New orthography } & \multicolumn{2}{|c|}{1923} & \multicolumn{2}{|c|}{1924} & \multicolumn{3}{|c|}{1925} & \multicolumn{2}{|c|}{1926} & \multicolumn{2}{|c|}{1927} & \multicolumn{2}{|c|}{1929} & \multicolumn{2}{|c|}{1930} & \multicolumn{2}{|c|}{1931} & \multicolumn{2}{|c|}{1933} & \multicolumn{2}{|c|}{1934} & \multicolumn{2}{|c|}{1935} \\
\hline & & & $\mathrm{H}$ & I & $\mathrm{H}$ & I & $\mathrm{H}$ & 1 & I $\quad \mathrm{H}$ & $\mathrm{H}$ & I & $\mathrm{H}$ & I & $\mathrm{H}$ & I & $\mathrm{H}$ & I & $\mathrm{H}$ & I & $\mathrm{H}$ & $\mathrm{I}$ & $\mathrm{H}$ & I & $\mathrm{H}$ & I \\
\hline 1 & Tugtoligssuaq & Tuttulissuaq & 5 & 20 & 4 & 19 & & & & 5 & 20 & & & & & & & & & & & & & & \\
\hline 2 & Nugssuaq & Nuussuaq & & & & & & & & & & & & & & & & & & 2 & 8 & & & & \\
\hline 3 & Navdlortoq & Nallortoq & & & & & & & & 3 & 12 & 5 & 21 & 4 & 23 & 5 & 19 & 4 & 17 & 4 & 17 & 3 & 8 & & 10 \\
\hline 4 & Saveqarfik (Savik) & Saveqarfik (Savik) & 3 & 14 & & & & & & & & & & 2 & 8 & 2 & 7 & 2 & 9 & & & & & & \\
\hline 5 & Savigssivik & Savissivik & & & 3 & 11 & 2 & & 5 & & & 4 & 11 & 3 & 14 & & & & & & & 7 & 31 & & 35 \\
\hline 6 & Qeqertaq u. & Qeqertaq (George Ø) & & & 3 & 17 & 2 & & 8 & & & & & & & 2 & 4 & & & & & & & & \\
\hline 7 & Qeqertaq $\mathrm{t}$. & Qeqertaq & & & 1 & 5 & 2 & 1 & 1 & 3 & 17 & 2 & 8 & 5 & 22 & 9 & 33 & 3 & 10 & 4 & 15 & 8 & 25 & & 15 \\
\hline 8 & Ivnanganeq & Innaanganeq & 5 & 22 & & & & & & 6 & 22 & & & 5 & 18 & 6 & 20 & 3 & 12 & 3 & 13 & 1 & 5 & & 14 \\
\hline 9 & Niaqornarssuk & Niaqornaarsuk & & & & & & & & & & & & & & & & 4 & 22 & 4 & 23 & & & & \\
\hline 10 & Sukat & Sukat & & & & & 4 & 1 & 7 & & & 4 & 20 & 1 & 6 & & & & & & & & & & \\
\hline 11 & Agpat & Appat & & & 1 & 5 & & & & & & & & & & & & & & & & & & & \\
\hline 12 & Ivssugigssoq & Issuissoq & & & & & & & & & & & & & & & & & & & & & & & 15 \\
\hline 13 & Umanaq (Thule) & Uummannaq & 6 & 33 & 3 & 19 & 11 & 4 & 31 & & 54 & 12 & 64 & 15 & 73 & 11 & 70 & 9 & 65 & 15 & 69 & 15 & 78 & & 66 \\
\hline 14 & Qeqertarssuit & Qeqertarsuit & & & & & & & & & & 12 & 10 & 3 & 19 & & & & & & & & & & \\
\hline 15 & Iterdlagssuaq & Iterlasuaq & & & & & 2 & 1 & 1 & 3 & 12 & & & & & & & & & & & & & & \\
\hline 16 & Natsilivik & Natsivilik & 5 & 29 & & & & & & & & & & & & & & & & & & & & & \\
\hline 17 & Uperngavigssuaq & Upernavisuaq & & & 3 & 11 & & & & & & & & & & & & & & & & & & & \\
\hline 18 & Qagssigssalik & Qassisalik & & & 5 & 35 & 8 & 2 & 6 & & & & & & & & & & & & & & & & \\
\hline 19 & Kiatak & Kiattaq & 3 & 13 & 2 & 14 & & 1 & 9 & 3 & 18 & 3 & 15 & 5 & 21 & 4 & 14 & & & 3 & 15 & 6 & 28 & & 12 \\
\hline 20 & Ulussat & Ulussat & 5 & 32 & & & & & & & & & & & & & & & & & & & & & \\
\hline 21 & Qeqertarssuaq & Qeqertarsuaq & 10 & 51 & 7 & 32 & & & & & & & & & & & & & & & & & & & \\
\hline 22 & Itivdleq & Itilleq & 2 & 9 & 3 & 15 & & & & 2 & 8 & & & & & 2 & 9 & & & & & & & & \\
\hline 23 & Kangerdlugssuaq & Kangerlussuaq & & & & & & & & & & & & 3 & 11 & & & 6 & 21 & 5 & 15 & & & & 15 \\
\hline 24 & Nunartarssuaq & Nunatarsuaq & & & & & & & & & & & & & & 2 & 8 & & & & & & & & 21 \\
\hline 25 & Qeqertat & Qeqertat & & & & & & & & & & & & 1 & 6 & 1 & 5 & & & & & 2 & 10 & & \\
\hline 26 & Qanaq & Qaanaaq & & & 9 & 47 & 9 & 5 & 21 & & 58 & 6 & 37 & & & 2 & 8 & 7 & 25 & & & 6 & 16 & & 13 \\
\hline 27 & Kangeq & Kangeq & & & & & & & & & & & & & & & & & & 2 & 6 & & & & 7 \\
\hline 28 & Kugkat & Kukkat & & & & & & & & & & 1 & 6 & 3 & 14 & 3 & 13 & & & 2 & 7 & & & & \\
\hline 29 & Siorapaluk & Siorapaluk & & & & & & & & & & & & & & 6 & 29 & 6 & 34 & 11 & 51 & 9 & 48 & & 29 \\
\hline 30 & Igdluluarssuit & Illuluarsuit & 1 & 2 & 1 & 4 & 6 & 2 & 8 & 5 & 24 & 5 & 21 & 2 & 6 & & & & & & & & & & \\
\hline 31 & Neqe & Neqi & 1 & 11 & 1 & 8 & 3 & 1 & 7 & & & 3 & 17 & 2 & 13 & 4 & 20 & 6 & 28 & 3 & 14 & & & & \\
\hline 32 & Ita & Iita & 2 & 8 & 2 & 7 & 2 & & 7 & 4 & 13 & 4 & 12 & & & & & & & & & 2 & 4 & & 8 \\
\hline 33 & Qamaerfit & Qamerfit & 3 & 12 & & & & & & & & & & & & & & & & & & & & & \\
\hline 34 & Anoritoq & Anoritooq & & & & & 3 & 1 & 1 & & & & & & & & & & & & & & & & \\
\hline 35 & Aunartoq & Aanartoq & & & & & & & & & & 5 & 19 & & & & & & & & & & & & \\
\hline \multirow[t]{2}{*}{36} & $\begin{array}{l}\text { Ellesmere Isl. } \\
\text { Fifth Thule Exp. }\end{array}$ & Ellesmere Island & & & & $\begin{array}{l}4 \\
7\end{array}$ & & & 9 & 3 & 9 & 4 & 15 & 3 & 7 & & 4 & 2 & 8 & & & & & & \\
\hline & Total & & 51 & 256 & 48 & 260 & 54 & 26 & 46 & & 2677 & 70 & 276 & 57 & 261 & 59 & 263 & 52 & 251 & 58 & 253 & 59 & 253 & & 260 \\
\hline
\end{tabular}

great hunters, great personalities, and explorers themselves, possessing a certain pioneer mindset (e.g., Rasmussen, 1919:82, 113; Malaurie, 1976). Notably, the establishment of the winter residence on Nuussuaq was a joint venture between father and son, as Kutsikitsoq moved his household to this remote site as well. However, the experiment lasted only one year. Some years earlier (1925), Kutsikitsoq, together with two other families, had established another short-lived winter settlement in Anoritooq in Inglefield Land, far north of the core settlement area. The best-known example of a pioneer settlement during the TSP is Tuttulissuaq in the southernmost part of the Melville Bugt, about $200 \mathrm{~km}$ southeast of the normal limit of the settled area. The hunter Uisaakasaq ('the great liar') moved there suddenly in 1910 with his own family and several others, and they established a settlement of four or five households. His dramatic history has been described in the literature (e.g., Gilberg, 1970), and the site was surveyed and test-excavated in 1979 (Grønnow and Meldgaard, 1980). Suffice it to say that a combination of Uisaakasaq's pioneer spirit, the promising caribou hunting, and, not least, serious social trouble, motivated this drastic move. By that time Tuttulissuaq had become a point of contact between Inughuit and the northernmost Inuit in West Greenland (Bryder, 1921:508), and it can be speculated that Uisaakasaq saw a potential role for himself as middleman between Avanersuaq and the colonial trading posts south of the Melville Bugt. Uisaakasaq's move came at an opportune moment for some families to follow him, both for social reasons and in order to benefit from being close to a great and generous hunter. The settlement at Tuttulissuaq was probably inhabited continuously until 1926, when disease struck and a young hunter, Angulluk, led the remaining settlers back to the settled area in the northern part of the bay (Hastrup, 2015:428).

\section{THE LOCATIONS OF THE HUNTING GROUNDS}

The sources of the TSP provide a rare opportunity to locate and characterize the hunting grounds. The productive ecosystem of the North Water polynya has an abundance of marine game year-round. Walrus (Odobenus odobenus), beluga (Delphinapterus leucas), narwhal (Monodon monoceros), ringed seal (Pusa hispida), and 

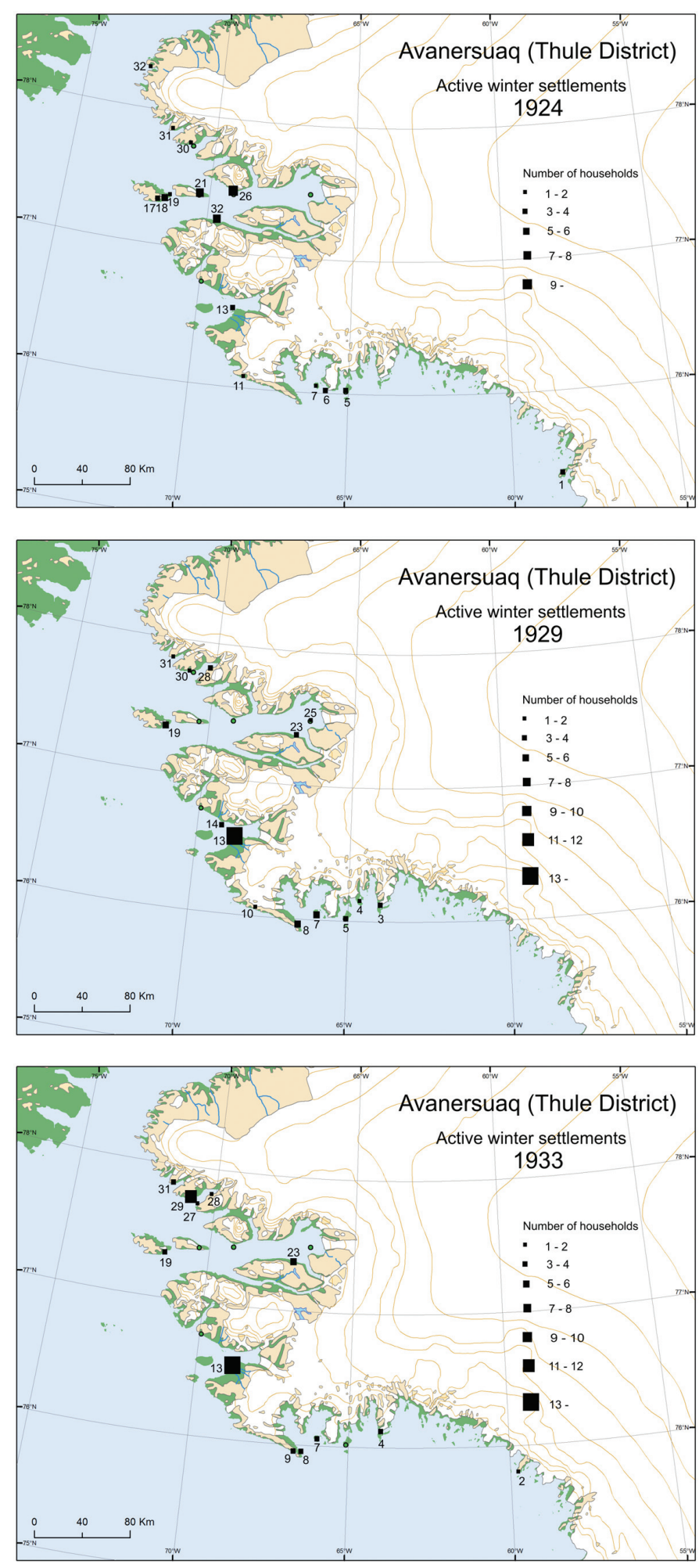

FIG. 3. The distribution and sizes (number of households) of winter settlements in Avanersuaq for three selected years: a) 1924, b) 1929, and c) 1933. Settlement place names are given in Table 1.

bearded seal (Erignathus barbatus) overwinter in the polynya in large numbers (Vibe, 1950; Heide-Jørgensen et al., 2016). However, the spatial distribution of hunting grounds is obviously not a direct reflection of the natural distribution of the game.
A key factor is accessibility to concentrations of game, which in turn is determined by sea ice conditions in two ways. First, safe transportation routes to and from resourcerich areas like ice ledges, ice edges, iceberg banks, tidal cracks, drift ice zones, and new ice are crucial. Such access roads over the sea ice were unevenly distributed and highly variable according to season. Hunting from kayaks during the spring and summer was dependent on ice conditions as well, as kayaks were often transported to the hunting grounds by dog sledge and launched from the ice edge. Second, the timing of the formation of ice ledges and zones with new smooth ice, as well as the seasonal opening and closing of the fjords, determined the migration routes and distribution of marine game and sea birds. Hunting success was a matter of observing, reading, predicting, and moving safely on the sea ice. It is possible to identify the position and character of the hunting grounds with accessible concentrations of resources during the TSP. For practical reasons, the analysis follows Rasmussen's division of the district.

\section{The Nigerliit Area}

The Nigerliit hunting grounds cover the Melville Bugt (Fig. 7), which is called Qimusseriarsuaq ('the Great Sledge Route') because of the vast plain of stable fast ice that remains in the bay for most of the year. Hunters took advantage of the Mouth of the Sea, the famous ice ledge that formed each spring and connected the southern and northern parts of the bay. Concentrations of migrating narwhal, beluga, walrus, and sometimes hooded seal (Cystophora cristata) made this ledge a rich hunting ground with excellent accessibility. Hunting of ringed seals and bearded seals was fruitful in the entire bay. The hunters emphasized that the spring hunt for uutoq (ringed seals basking on the ice) was particularly rewarding (Vibe, 1950:66). The inner part of the bay was difficult to access because of deep snow cover, but some polar bear (Ursus maritimus) hunting took place there. The drift ice zone quite far south of Kap York provided a famous but risky hunting ground for polar bear (Holtved, 1935 - 37:174). Intensive spring and summer netting of Little Auks (Alle alle) took place at the rich colonies in the northernmost bay, and its iceberg banks were also considered fine hunting grounds for ringed seal. During the early TSP period, caribou were successfully hunted on headlands in the southern part of the bay.

\section{The Akunnaarmiut Area}

Wolstenholme Fjord offered important areas with resource concentrations (Fig. 8). Most prominent among these were the southern entrance to the fjord and the sea around the island of Appat (Saunders Ø) in the mouth of the fjord. During early spring and autumn, the hunters harpooned walrus in tidal ledges and openings there, and the areas of smooth and transparent ice that formed around the island as a result of refreezing of open patches were 


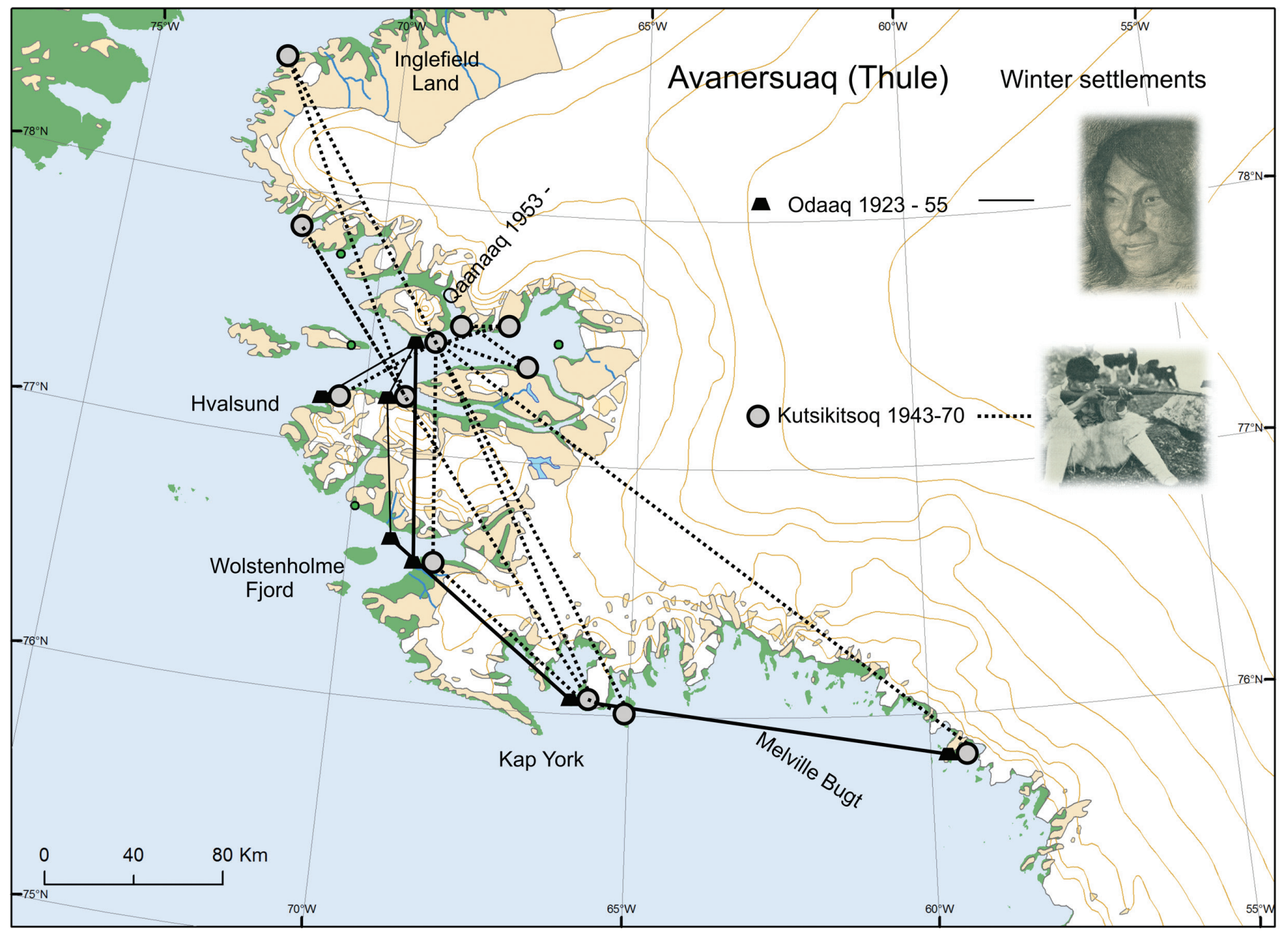

FIG. 4. The winter settlements of the Odaaq and Kutsikitsoq families. Source: Holtved, 1944.

walrus grounds par excellence (Holtved, 1967:100 - 103; Freuchen and Salomonsen, 1961:329). North of the island, at the mouth of Granville Fjord, walrus were hunted in open water areas in early spring.

The Appat area offered remarkably rich bird resources (including eggs): Thick-billed Murres (Uria lomvia) nested on bird cliffs on the northern coast, and eiders were abundant on the small islands south of the island. Ringed seals and some bearded seals were hunted all over the fjord in all seasons, particularly along its northern coast. Some belugas were harpooned during the open water season (Holtved, 1967:91). Hunting of King Eiders (Somateria spectabilis) and Snow Geese (Chen caerulescens) took place in the hinterland and south of the Uummannaq settlement, where fox (Vulpes lagopus) trapping was also carried out (Rasmussen, 1921:532, 560). No comparable resource concentrations existed along the west coast of the Kap York peninsula, but the settlers of this coast took advantage of vast numbers of Little Auk, fox, and hare (Lepus arcticus), and they had access to southward-migrating walrus close to the coast during fall.

\section{The Oqqorliit Area}

The Oqqorliit district contained several resource concentrations, and a great variety of game was exploited (Fig. 9). The sources highlight the strait to the south, Hvalsund (Ikersuaq), leading into the main fjord, Inglefield Bredning (Kangerlussuaq), a prime hunting ground for walrus, migrating narwhal, and beluga following the retreat of the fast ice edge in spring and early summer (Vibe, 1950:77 -85). Walrus was taken here, as well, during fall, and ringed seal hunting was remarkably rich. Ikerasak, a narrow strait between the two islands in the mouth of Inglefield Bredning with year-round open water, could be designated a resource hot spot, with many ringed seals, as well as Little Auk colonies on the south coast of Northumberland Ø (Vibe, 1950:16). To the west, the small island of Appaarssuit (Hakluyt $\varnothing$ ) attracted hunters to nesting colonies of Thickbilled Murres on its cliffs, even if the island was difficult to access (Gilberg, 1971:64).

Rich ringed seal hunting grounds were found along the south side of Inglefield Bredning, which also provided access to narwhals following ice ledges and the retreating fast ice edge. However, the most rewarding narwhal 


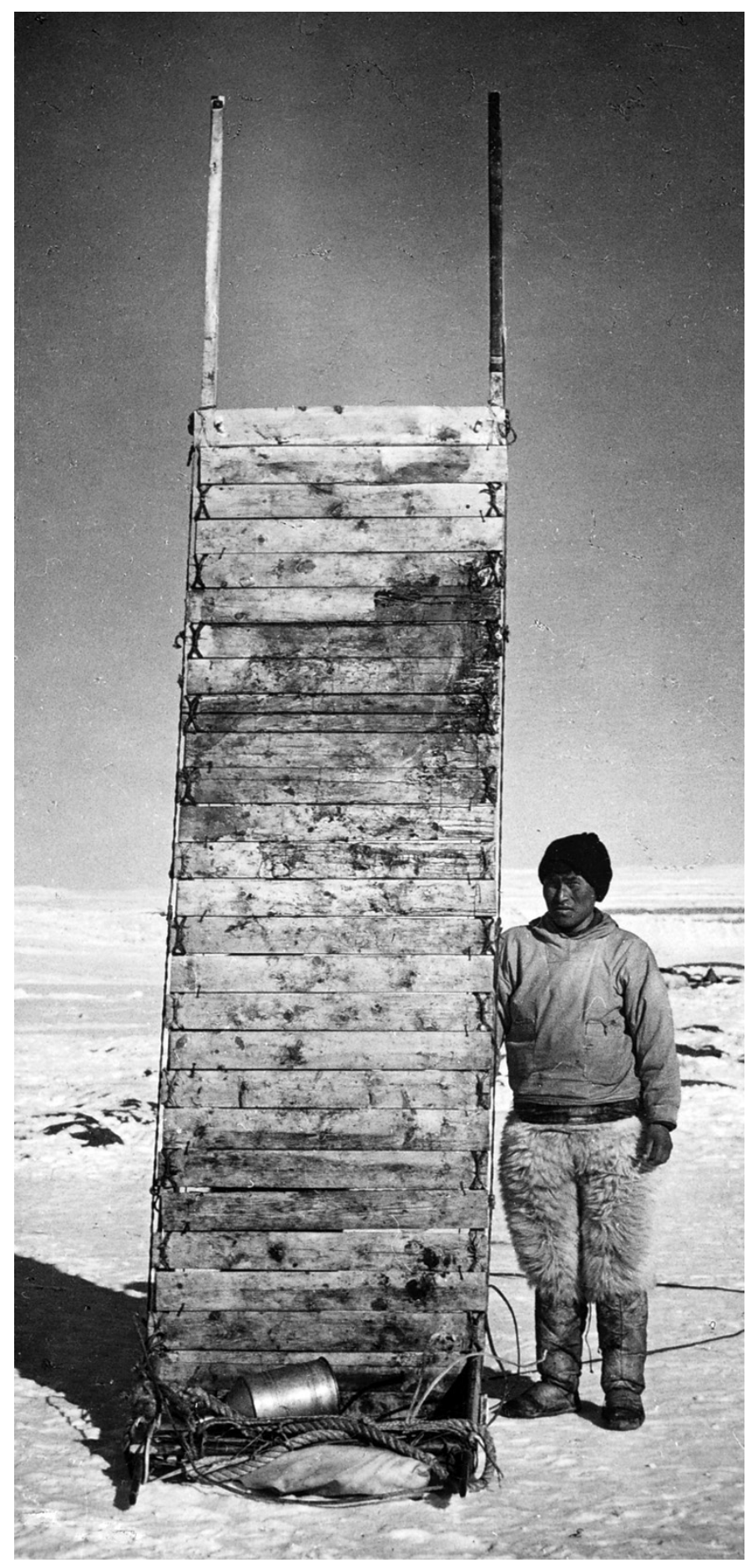

FIG. 5. Kutsikitsoq with his large dog sledge. Photo: Erik Holtved, 1936. The National Museum of Denmark.

hunting took place in open water around Qeqertat in the inner fjord. This area offered other opportunities: hunting of ringed seal on new ice and as uutoq. According to Rasmussen (1921:539), the very best narwhal hunting site in the entire Thule region was Quinissut on the northern coast of the inner fjord. The iceberg bank between Herbert $\varnothing$ and the Qaanaaq settlement on the mainland was an attractive hunting ground. The ledges and open water patches formed by tidal waves around the grounded icebergs offered great

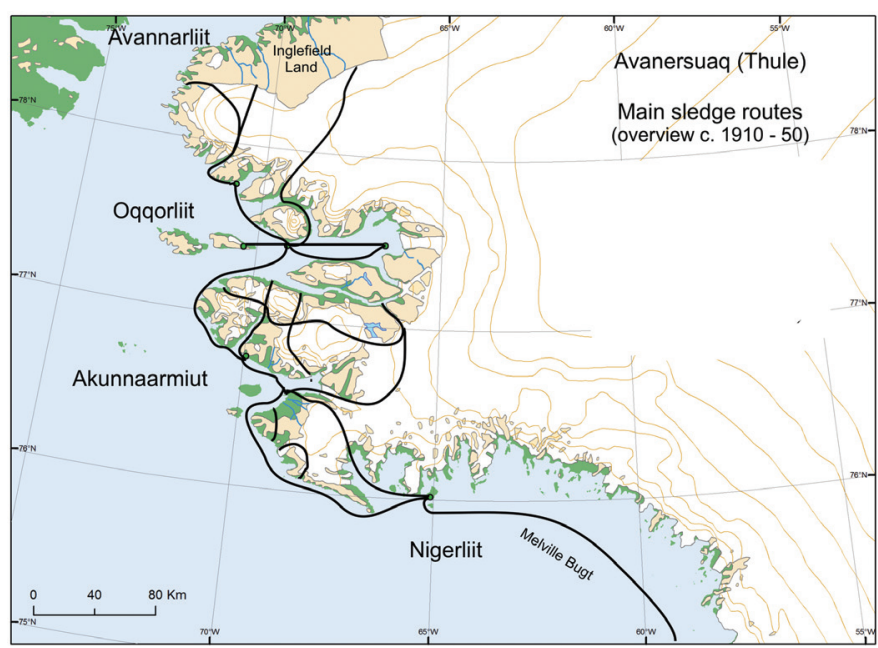

FIG. 6. The main sledge routes in Avanersuaq, c. 1910-50 (Gilberg, 1971; Holtved, 1935-37, with additions).

hunting of ringed seal, supplemented with walrus and narwhal (Gilberg 1971:71).

Last but not least, the area near Siorapaluk was pivotal (Rasmussen, 1921:535; Holtved, 1935 - 37:213, 1967:101). There, sea currents constantly reshaped the sea ice that covered bivalve banks, where numerous walrus grazed. The hunting of these animals on new ice off Neqi and Pitorafik was legendary. Families from distant winter sites gathered there, built snow houses or qarmat (shelters), and joined the families that already occupied turf houses at this locale (Rasmussen, 1921: Pl. XCII). Meat and blubber from walrus hunting on new ice at these sites were almost a precondition for human existence in the entire northern Avanersuaq, perhaps in the entire region. Later in spring, walrus were an important target along the ice edges and in the openings at the mouths of the small fjords. This northern concentration of resources was also supplemented by large colonies of Little Auk and the foxes and hares that thrived at these locations.

The formerly large caribou population in the region was decimated both before and during the TSP as a result of hunting with rifles. Caribou skins for clothing were thus in great demand; consequently, caribou skins were imported from West Greenland and sold at the trading stations (Holtved, 1967:34). However, caribou hunting was to a certain extent still conducted north and south of Olrik Fjord and around Bowdoin Fjord, where people also fished for Arctic char (Salvelinus alpinus) in rivers and from new, transparent ice on lakes (Rasmussen, 1921:533; Freuchen and Salomonsen, 1961:288).

\section{The Avannarliit Area}

This area encompassed the northernmost district, from Kap Alexander via Inglefield Land to Washington Land (Fig. 10). The winter habitation here was neither intensive nor continuous. However, Iita is highlighted in the sources for its huge Little Auk colony, the northernmost of 


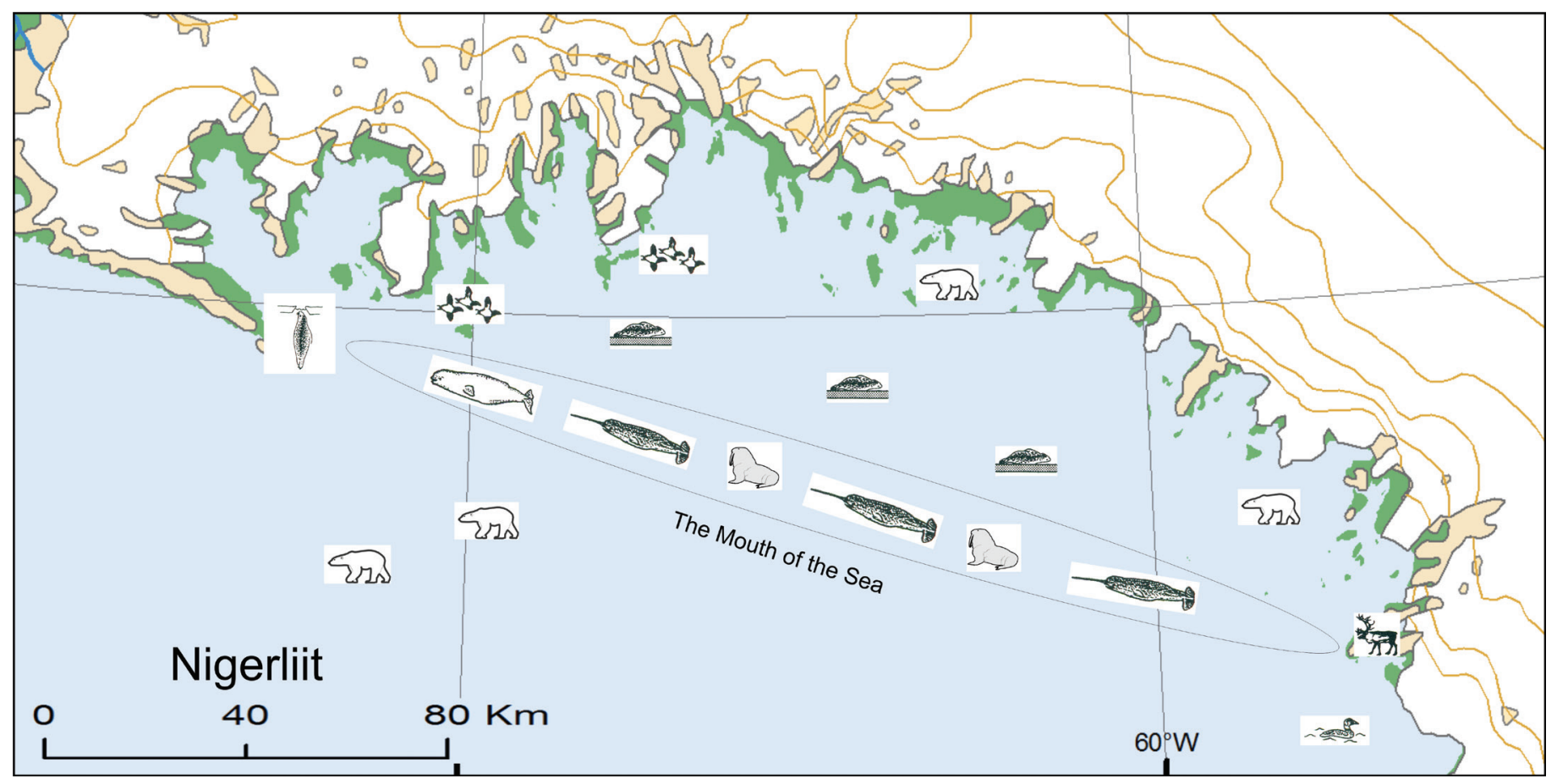

FIG. 7. The main hunting grounds in the Nigerliit area.

them all, and the potential for walrus hunting in the Foulke Fjord region. Farther north, the coast from Hatherton Bay to Anoritooq offered ice edge and drift ice conditions for hunting walrus, narwhal, ringed seal (rich uutoq hunting), and polar bear, as well as gathering eider eggs (Littleton Island) (Vibe, 1950:25, 28-29; Freuchen and Salomonsen, 1961:187).

The interior must be mentioned as an important caribou hunting area. It became the target of hunting parties traveling to the area via sledge routes over the Ice Cap. Farther north, beyond the Humboldt Glacier, an area with broken ice south of Washington Land offered a rewarding seal hunting ground, even if it was difficult to access (Rasmussen, 1921:541 - 543).

Muskoxen (Ovibos moschatus) were rare or absent in Inglefield Land during the TSP, but this species was hunted, along with polar bear and to some extent caribou, by groups of hunters and some families who made long expeditions lasting six to eight weeks across the ice of the Nares Strait to Ellesmere Island (Rasmussen, 1921:561-562; Holtved, 1935 - 37:572). The accessibility of the exotic but important resources on Ellesmere varied considerably during the TSP, primarily because of politically determined hunting restrictions. By establishing and running an RCMP post (the Bache Detachment) in the years 1926-33, the Canadian Government marked its sovereignty over Ellesmere and prohibited hunting by the Inughuit on the western side of Smith Sound. The ban was not strictly observed, and when the station was abandoned, the Inughuit hunting expeditions were resumed (Vibe, 1948; Schledermann, 1996, 2003).

\section{Euro-American Resource Concentrations}

The influence of the Euro-American traders, explorers, and their expedition headquarters must also be considered. During the TSP, trade with Euro-Americans on board expedition vessels was sparse and did not influence Inughuit settlement patterns as it had done earlier in the 19th century, when Inughuit were attracted to Kap York by the trading opportunities with whalers in spring (Freuchen and Salomonsen, 1961:183). Also before the TSP, the expedition headquarters of the Peary era, one in Bowdoin Fjord and one west of Qaanaaq, attracted a number of Inughuit hunters and supplied them with guns and provisions (Peary, 1898; Astrup, 1895:87). However, when the grand-scale American expeditions ceased, only the headquarters of McMillan's expeditions in Iita remained active until 1917. Some Inughuit families settled there, where they subsisted on a mix of local marine game, Little Auks, and Western foods (Darwent and Johansen, 2010; Johansen, 2013). After 1917, Iita was inhabited by two to four families well into the TSP.

The establishment of the Thule Station in 1910 (Fig. 11) resulted in marked changes in Inughuit subsistence and settlement patterns. The station attracted people from earlier substantial winter settlements in the vicinity, and soon practically all Inughuit families settled for some time at the Uummannaq site during their frequent shifts of winter location, as described above for Odaaq and his son. During the 1930 s, no less than $25 \%$ (65-78 individuals) of the total population of 250-265 was living at Uummannaq, next to the trading station. However, only a few became permanent settlers there. The Council of the Hunters (Fangerraadet) at 


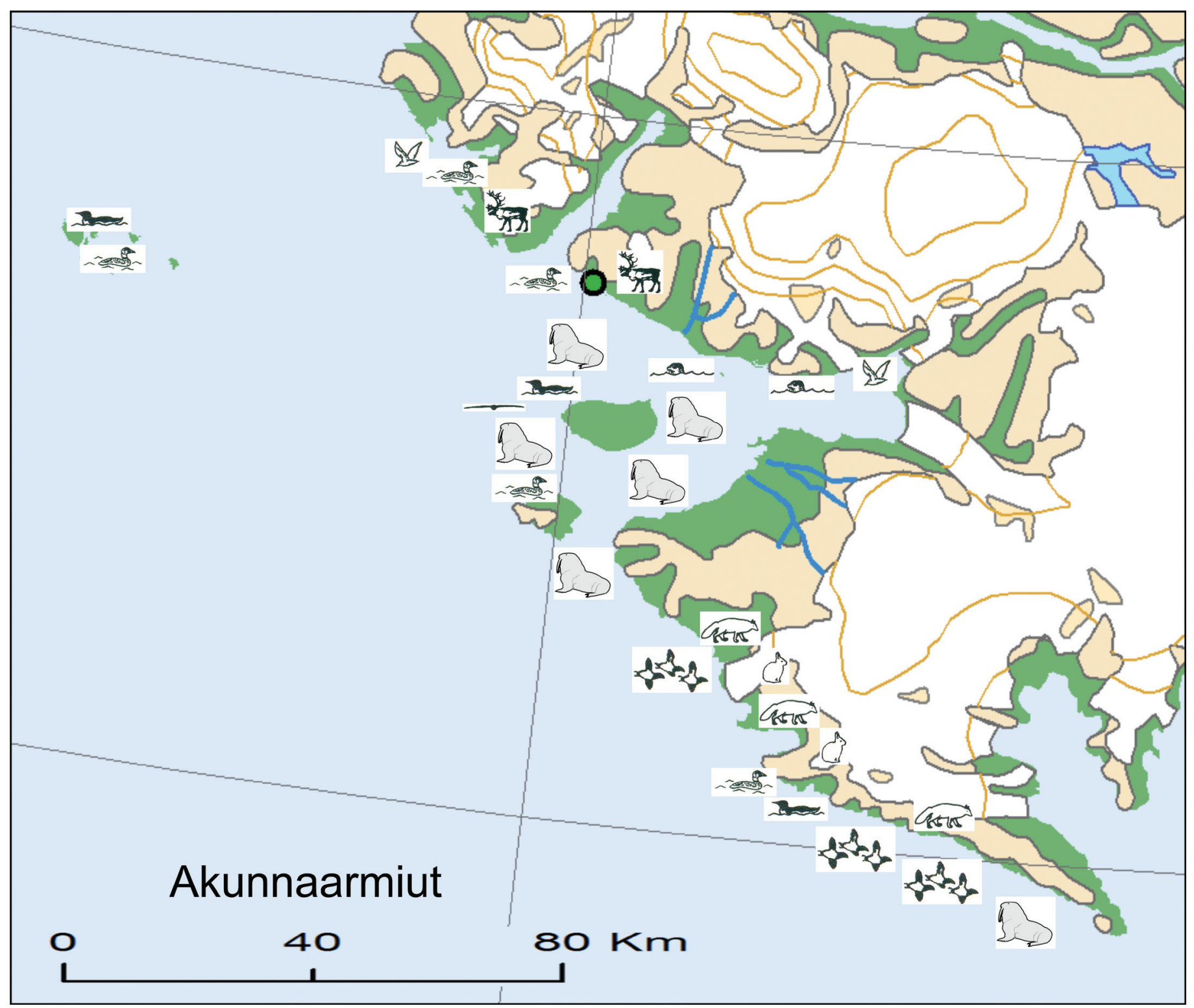

FIG. 8. The main hunting grounds in the Akunnaarmiut area.

the Station passed a law in 1930 that made it illegal for families to stay more than three consecutive years at the site (Hastrup, 2015:354-356). Maintenance of a dispersed settlement pattern certainly furthered the fox trapping of the Inughuit, and the profit from the fox fur trade was essential for the economy of the Thule Station (and the financing of Knud Rasmussen's expeditions).

The international demand for fur was generally high throughout the TSP, and the trade resulted in unprecedented wealth among Inughuit. Part of this profit was spent on luxury goods such as tobacco and coffee, but a great deal was invested in materials like wood and metals that could be effectively incorporated into the traditional hunting technology, facilitating the development of the advanced dog sledge complex. When trading posts were established in Siorapaluk and Savissivik, they became focal sites and influenced the Inughuit settlement pattern, but on a smaller scale than the Thule Station. The presence of the Danish Mission, with its school chapels at the trading posts and its church and tiny hospital with a permanent doctor in Thule, obviously made the posts attractive. The Thule Station and the two trading posts were also appealing because they provided some insurance against food shortages and outright starvation. Though the posts were private enterprises until 1936, they had colonial-like effects on the local Inughuit.

\section{THE SEASONAL RANGE OF POSSIBILITIES}

The use of biotic resources by the Inughuit can be investigated further by constructing a schematic cycle that models the range of possibilities on which the strategic priorities of the hunters were based (Fig. 12). The model does not present a specific annual cycle of an Inughuit family because, 


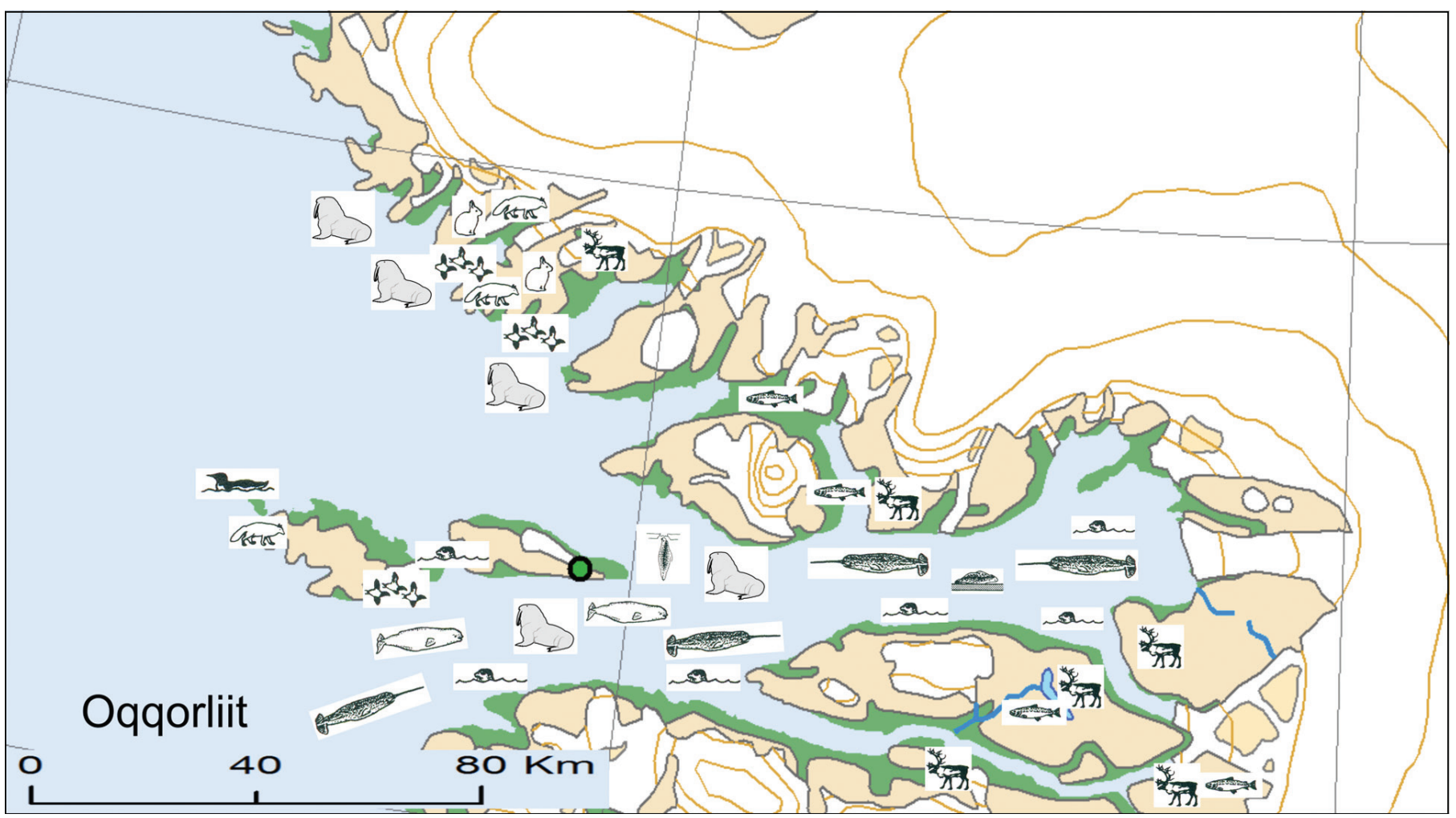

FIG. 9. The main hunting grounds in the Oqqorliit area.

as we have seen, preconditions for living in the areaaccessibility of game and social relations - were dynamic. The following information elaborates the model:

- The dark period from November to February and the short days surrounding this period restricted the possibilities for hunters to find game.

- Accessibility, quantity, and species of game varied considerably according to season.

- The stone built caches were filled during the spring and early summer resource boom, but fall hunting also added to the stores. The amount of stored meat and blubber was crucial to avoid hunger and provide light and heat during the dark months and early spring, before the return of the migrating game. Caches were often placed at dispersed seasonal hunting sites at some distance from the winter settlements. Thus, sea ice conditions helped determine the possibilities to bring stored food and fuel back to the winter sites.

- Ringed seal was a basic resource. It was one of the very few game species accessible during the dark months (hunting at breathing holes and tidal cracks along glacier fronts and headlands). Ringed seal was a bulk resource at the iceberg banks and as uutoq during spring. Bearded seals were hunted in much the same way as ringed seals, although in smaller quantities (Vibe, 1950:54 - 64).

- Walrus was a main bulk resource. Without tons of meat and fuel (blubber) from walrus, human life at the North Water would have been impossible. Almost all families participated in spring and fall hunting on new ice.
Walrus was also hunted during spring along the ice edges as the fast ice melted back and the edges reached the shallow feeding grounds of the animals. Late spring hunts took advantage of walrus that were resting on ice floes in the fjords. In fall, walrus were caught from kayaks in open water, often assisted by motorboats from the trading posts (until October, when new ice began to form). Some animals passed along the southern coasts of the district during their fall migration and were hunted there.

- Narwhal and beluga were hunted along ice ledges in spring and along the ice edges following the retreat of the fast ice. Late spring and summer narwhal hunts in the inner fjords were of great importance and added considerably to the stored supplies.

- Polar bear hunts were conducted during the winter months, preferably in the drift ice and while there were still some daylight hours.

- Though seabird exploitation was restricted to three or four spring and summer months of the year, the birds formed a bulk resource for the Inughuit. Fulmars were the first seabirds to arrive in spring, and in June millions of Little Auks reached their colonies, where they were netted by the thousands (Johansen, 2013). They were eaten immediately or fermented in sealskins to be consumed several months later. The Thick-billed Murre nesting cliffs yielded quantities of birds and eggs, but eider colonies were the primary source for eggs, which were collected and cached for later consumption (Freuchen and Salomonsen, 1961:186-194). 


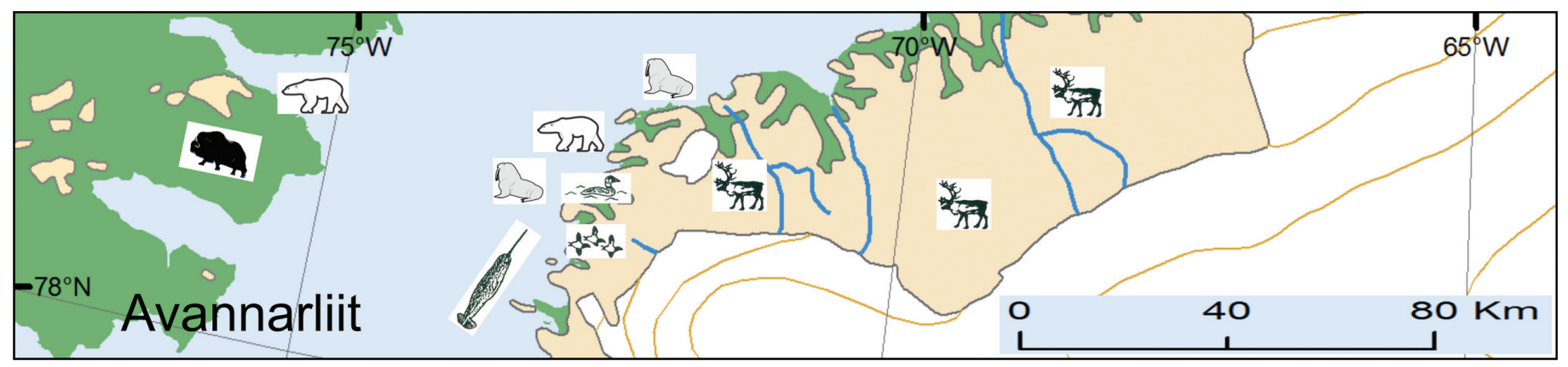

FIG. 10. The main hunting grounds in the Avannarliit area.

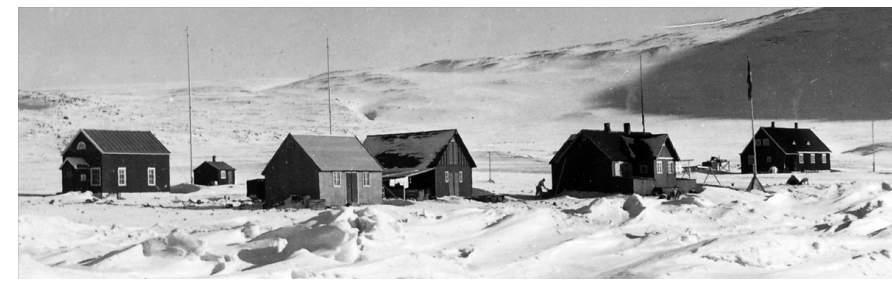

FIG. 11. The Thule Station, spring 1936. Photo: Erik Holtved. The National Museum of Denmark.

- Caribou were hunted mainly during spring and autumn and mostly in distant interior areas, where the hunt was combined with Arctic char fishing.

- Arctic fox and polar hare were caught in large quantities. Hares were snared by means of fences (long cairn rows with snares), and foxes were trapped primarily during winter by means of modern metal traps. Fox meat was appreciated and consumed during winter (Rasmussen, 1921:560). Ptarmigan (Lagopus sp.) were taken primarily during the cold months.

- When the daylight returned for a few hours in February and March, small parties of hunters (sometimes with their families) went on lengthy polar bear, muskox, and caribou hunting trips on the east coast of Ellesmere Island.

- Fur trade at the stations, in particular at the Thule Station itself, was part of the range of options for Inughuit. This trade influenced decisions about where to settle during the year.

- The annual cycle clearly shows the two meagre seasons in which the range of hunting possibilities was quite narrow. In summer, large marine game was dispersed in open water and difficult to get at (kayak hunting), and birds became an important resource. However, during the TSP, summer was not described as a starvation period as it had been earlier (Rasmussen, 1921:531), probably because of back-up provisions from the trading posts and assistance with hunting activities (Holtved, 1935 - 37:80). Midwinter and late winter, on the other hand, were still critical because not much game was accessible and the caches were often empty by that time of the year.

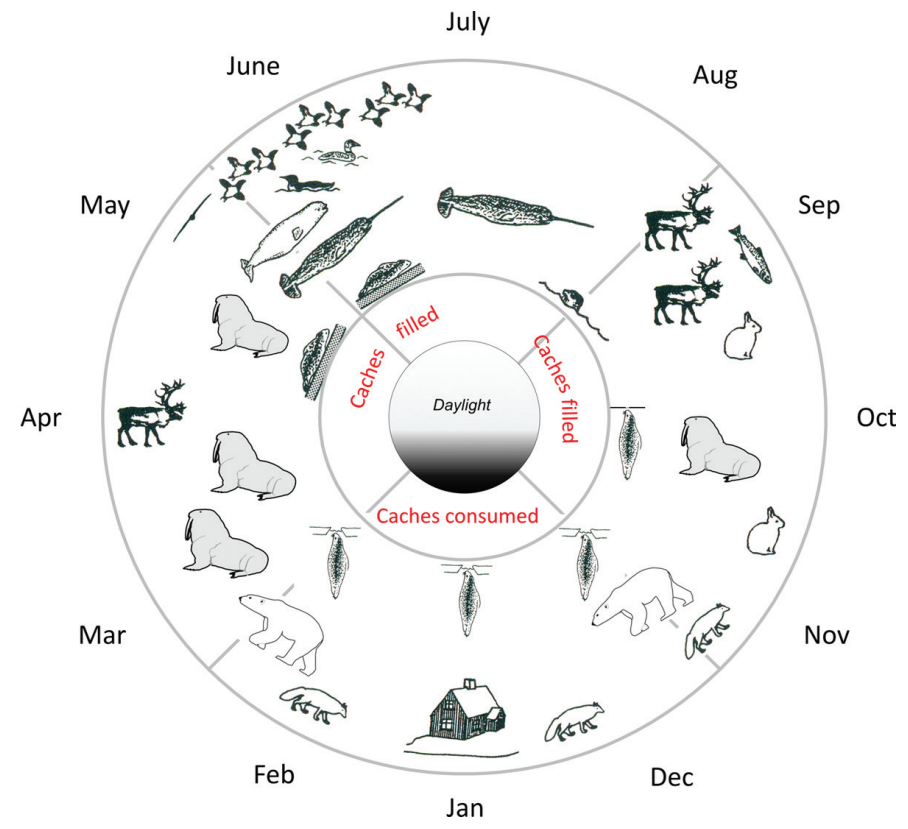

FIG. 12. Model of the annual range of hunting possibilities during the Thule Station Period.

\section{Strategies and Risks}

The analyses show that the Inughuit use of biotic resources boomed in the early spring and early summer months. The availability of resources was optimal, and spring was the only season when the Inughuit population gathered at a few specialized aggregation sites for walrus hunting. Without these bulk resources of meat and blubber, the extremely energy demanding dog sledge complex of the TSP could not have been maintained. In late spring and early summer, the rich uutoq hunting of ringed seals, catching of seabirds (Little Auk), collection of eggs, and narwhal hunting contributed to what must have been the most important strategic goal of the Inughuit: to accumulate as many resources as possible for later consumption. If a hunter chose to cross the icebound Nares Strait to go muskox and caribou hunting on Ellesmere Island, he could miss hunting opportunities on the Thule side, such as the important spring walrus hunt. So the strategy of making long hunting expeditions could result in a considerable return of exotic and much appreciated resources, but it definitely involved elements of risk. 
During summer, when open water dominated the seascape, the harvest of biotic resources was in fact quite modest. Before the TSP, old people and children were often left in camps next to eider or Little Auk colonies, while the more mobile members of the household went hunting for dispersed seals in open water. Groups of families faced the risk of being isolated not only from the rest of the society, but also from their spring caches, and isolation was an obvious risk that influenced the choice of summer campsites.

Hunters' strategies during late summer and early fall aimed to exploit the formation of new sea ice. Walrus and seal hunting became rewarding again on new ice, so that a surplus could be cached to supplement the spring caches. Ideally, people could add caribou hunting and Arctic char fishing in the interior, or alternatively, hunt migrating walrus along the coasts. As the maps show, however, the hunting grounds were far from each other, and hunters had to make difficult strategic choices between these overlapping alternatives about where and when to settle their families.

Winter subsistence and settlement strategies had three main goals: security, prestige, and trade. Security was obtained by settling at winter sites with opportunities for ringed seal hunting on stable fast ice or close to iceberg banks. Sites with optimal access to sledge routes to and from meat and blubber caches also increased security. The goal of security also influenced the hunters' choice of fellow settlers: it was important to stay with great hunters who had ample supplies. Finally, some families chose to settle for the winter near trading posts.

Prestige was gained mainly through polar bear hunting. Sledge journeys far out into the drift ice zone in the southern part of the North Water took the hunters to the polar bear grounds. During the TSP, rifles had minimized the risk of being killed during the hunt itself, but hunting for weeks in the drift ice was still a very dangerous enterprise.

Winter was the peak season of trade, which demanded lots of high-quality fox skins. Winter hunting strategies were therefore strongly influenced by access to productive trap lines. Late winter was the real meagre period of the annual cycle, so the hunting strategy was focused on survival. Ringed seal hunting was difficult in the darkness, and during some winters, dogs and people faced hunger. The return of the light and the spring resource boom were eagerly anticipated.

\section{CONCLUSIONS}

The analysis of the subsistence and settlement of the Inughuit during the period 1910-53 has shown how a pattern emerged from a complex of strategic choices made by individual hunting families (c. 60 families, 270 individuals). We have seen that the dispersed winter settlement pattern in the district resulted from frequent, and often very long, moves of the families' residences, on average every second year. The families selected from at least 35 named winter locations, of which ca. $25 \%$ to $40 \%$ were inhabited each winter, typically by four families.

A few Inughuit settlements were larger aggregation camps. Some were starting points for spring walrus hunts on new ice, where the families gathered once a year and coordinated their activities to fill the meat caches. Other focal sites were Uummannaq at the Thule Station and the settlements at the trading posts in Siorapaluk and Savissivik, which attracted people with their chapels and schools and the opportunity to trade fox furs for luxury goods and materials, as well as their relative insurance against starvation. Along with the use of the biotic resources, these "colonial" factors carried weight in the strategic considerations about where families settled, for how long, and with whom they stayed at a site. In the $1930 \mathrm{~s}$, about 25\% (65-78 individuals) of the total population stayed periodically at Uummannaq during their long-term movements between sites in the district. The founding of pioneer sites was also an integral part of the pattern; the desire to experiment and to take chances - a pioneer spirit - was an important component of the Inughuit settlement and subsistence strategy.

The success of the strategy was dependent on the hunting families' social flexibility, extreme mobility, and ability to accumulate and transport bulk food and fuel for later consumption during meagre seasons. During the TSP, the dog sledge complex developed remarkably, so that entire families and heavy loads of gear, food, and blubber could be moved around in the district very efficiently via a dense network of sledge routes on the sea ice, as well as on the Ice Cap.

The analysis of the locations of Inughuit hunting grounds during the TSP showed that each of the four geographical districts offered important concentrations of biotic resources from the rich ecosystem of the North Water polynya. In the southernmost district, the hunting grounds for big marine game were located at the tidal crack, the "Mouth of the Sea." In the Wolstenholme Fjord district, the most important hunting grounds were found at the southern part of the mouth of the fjord and around the island of Appat. In the Inglefield Bredning area, hunting of large marine mammals took advantage of resource concentrations around the islands in the mouth of the fjord, in the inner fjord, and off the coasts of Siorapaluk. The hunting grounds of the northernmost part of Avanersuaq, Inglefield Land, were situated around Iita and farther north, but except for the caribou hunting grounds in the interior, they were used only sporadically. Finally, Ellesmere Island on the Canadian side of the Nares Strait was an important hunting ground for muskox.

The accessibility of indispensable marine resourcesmainly ringed seal, walrus, narwhal, and seabirds - was obviously determined by sea ice conditions. The most productive hunting grounds were situated in transitional zones, where openings, ice ledges, fast ice edges, tidal cracks, iceberg banks, and new ice formed. It demanded profound experience to read this ever-changing icescape and navigate 
it safely while hunting. Thus, the residential moves of families, which over time (decades) took them to all parts of Avanersuaq, can be viewed as a means to accumulate the necessary firsthand knowledge of and experience with the various resource concentrations of the entire district.

The schematic model of the seasonal range of hunting possibilities made it clear that strategic decisions about where and when to hunt (and with whom) were crucial to the well-being of Inughuit families. There was apparently a multitude of resources to choose from during the annual cycle, but the seasonal resource variations were huge and never the same from one year to another. In two critical seasons, summer and mid-to-late winter, food and fuel were sparse or absent. Thus, Inughuit subsistence was based on resource accumulation: bulk resources from the spring boom, including walrus and narwhal meat and blubber, were stored to be consumed (and shared) later.

The analysis of the annual cycle of potential resources shows that Inughuit hunters used season-specific strategies to obtain material and social security throughout the year and minimize risk. It apparently worked very well during the Thule Station Period: life in the four decades from 1910 to 1953 was generally good. Bad years due to infectious diseases occurred, but for the most part hunting and trade boomed, and great events and remarkable men and women from this period are still vividly and positively remembered among the Inughuit of today (e.g., Hastrup, 2015:244).

Finally, it must be emphasized that the picture drawn here of Inughuit settlement and subsistence is simplified for analytical reasons. Environment, biotic resources, political circumstances, technology, and demography entered into complex interplays during the TSP and made each year different. The same diversity obviously existed over longer time spans. Settlement and subsistence patterns around 1850,1910 , and 1980, as illustrated by the schematic reconstructions of Gilberg (1984:579), were quite different from each other and from the situation described above. And the complexity increases considerably when settlement and subsistence around the North Water polynya are explored through archaeological sources and approaches. The current NOW Project has taken up the challenge of studying these long-term trends in more detail (Hastrup et al., 2015).

\section{ACKNOWLEDGEMENTS}

I wish to thank all members of the NOW team for inspiring discussions and assistance with this paper: Astrid O. Andersen, Martin Appelt, Thomas A. Davidson, Rune Dietz, Janne Flora, Anne Birgitte Gotfredsen, Kirsten Hastrup, Kasper Lambert Johansen, Mads Peter Heide-Jørgensen, Jens Fog Jensen, Erik Jeppesen, Anders Mosbech, Mikkel Myrup, and Asta Mønsted. The NOW Project is funded by the Velux Foundations and the Carlsberg Foundation. I extend my warm thanks to the organizers of the Priscilla Renouf memorial session at the CAA meeting in St. John's, Newfoundland, in 2015. It is an honour to contribute to this volume of Arctic, and I dedicate my paper to the memory of Priscilla.

\section{REFERENCES}

Andreasen, C., and Elling, H. 1991. De arkæologiske undersøgelser [The archaeological investigations]. In: Egede, I., ed. Naturbevaring i Grønland: Forskning, natur- og vildtforvaltning [Environmental protection in Greenland: Research, management of environment and game]. Nuuk: Attuakiorfik. 54-65.

Appelt, M., and Gulløv, H.C., eds. 1999. Late Dorset in High Arctic Greenland: Final report on the Gateway to Greenland Project. Danish Polar Centre Publication 7. Copenhagen: Nationalmuseet and Dansk Polarcenter.

Astrup, E. 1895. Blandt Nordpolens Naboer [Among the neighbours of the North Pole]. Kristiania [Oslo]: H.A. Aschehoug.

Bessels, E. 1884. The northernmost inhabitants of the Earth: An ethnographic sketch. American Naturalist 18(9):861-882. http://dx.doi.org/10.1086/273755

Born, E.W. 1987. Aspects of present-day maritime subsistence hunting in the Thule area, North West Greenland. In: Hacqueboard, L., and Vaughan, R., eds. Between Greenland and America: Cross-cultural contacts and the environment in the Baffin Bay area. Works of the Arctic Centre, No. 10. Groningen, Netherlands: Arctic Centre. 109-132.

Born, E.W., and Böcher, J., eds. 2001. The ecology of Greenland. Nuuk: Atuakkiorfik Education.

Bryder, H. 1921. Upernivik Distrikt. Meddelelser om Grønland 60:430-508. Copenhagen: Kommissionen for Videnskabelige Undersøgelser i Grønland.

Darwent, J., and Johansen, T.B. 2010. Archaeological survey in the Foulke Fjord region, Inglefield Land, northwestern Greenland. Geografisk Tidsskrift-Danish Journal of Geography 110(2):297-314. http://dx.doi.org/10.1080/00167223.2010.10669513

Freuchen, P., and Salomonsen, F. 1961. Det arktiske år [The Arctic year]. Copenhagen: Gyldendal.

Gilberg, R. 1970. Uisâkavsak, “The Big Liar.” Folk 11/12:83-95. - 1971. Polareskimoerne i Thule Distriktet, Nordgrønland: Økologiske betragtninger over bosætning og demografi [The Polar Eskimos in the Thule District, North Greenland: Ecological considerations concerning settlement and demography]. Unpubl. manuscript. The Library of the Ethnographic Collections, The National Museum of Denmark, Frederiksholms Kanal 12, DK-1220 Copenhagen, Denmark.

- 1976. The Polar Eskimo population, Thule District, North Greenland. Meddelelser om Grønland 203(3). Copenhagen: Kommissionen for Videnskabelige Undersøgelser i Grønland. 1984. Polar Eskimo. In: Damas, D., ed. Handbook of North American Indians, Vol. 5 - Arctic. Washington Smithsonian Institution. 577-594.

. 1994. Mennesket Minik (1888-1918): En grønlænders liv mellem 2 verdener [Mennesket Minik (1888-1918): A Greenlander's life between two worlds]. Espergærde, Denmark: Ilbe. 
Gotfredsen, A.B. 2010. Faunal remains from the Wollaston Forland - Clavering Ø Region, Northeast Greenland - Thule culture subsistence in a High Arctic polynya and ice-edge habitat. Geografisk Tidsskrift-Danish Journal of Geography 110(2):175-200.

http://dx.doi.org/10.1080/00167223.2010.10669506

Grønnow, B. 2010. The history of archaeological research in North East Greenland: Putting the GeoArk Project into perspective. Geografisk Tidsskrift_Danish Journal of Geography 110(2):117-129.

http://dx.doi.org/10.1080/00167223.2010.10669502

Grønnow, B., and Meldgaard, M. 1980. Archaeological investigations. In: Jacobsen, N.K., ed. The Knud Rasmussen Memorial Expedition: Report of activities at Tugtuligssuaq, Melville Bugt, 1978-79, by C. Bay, B. Fredskild, B. Grønnow, B.H. Jakobsen, M. Meldgaard, N.G. Mortensen, and N. Thingvad. Geografisk Tidsskrift 80. 41-44.

Grønnow, B., and Sørensen, M. 2006. Palaeo-Eskimo migrations into Greenland: The Canadian connection. In: Arneborg, J., and Grønnow, B., eds. Dynamics of northern societies: Proceedings of the SILA/NABO Conference on Arctic and North Atlantic Archaeology, 10-14 May 2004, Copenhagen. National Museum Studies in Archaeology \& History, Vol. 10. Copenhagen. 59-74.

Grønnow, B., Sørensen, M., and Gotfredsen, A.B. 2015. Arkæologiske og arkæo-zoologiske registreringer i Kap York-området, NOW Projektet, 2014 [Archaeological and archaeozoological surveys in the Cape York area, the NOW Project, 2014]. Report nr. 35. Copenhagen: SILA - The Greenland Research Centre at the National Museum of Denmark.

Hastrup, K. 2015. Thule på tidens rand [Thule at the edge of time]. Copenhagen: Lindhardt og Ringhof Forlag.

Hastrup, K., Grønnow, B., and Mosbech, A. 2015. The NOW Project: Living resources and human societies around the North Water in the Thule Area, NW Greenland. Annual Report 2014. University of Copenhagen.

Heide-Jørgensen, M.P., Sinding, M.-H.S., Nielsen, N.H., RosingAsvid, A., and Hansen, R.G. 2016. Large numbers of marine mammals winter in the North Water polynya. Polar Biology 39(9):1605-1614. http://dx.doi.org/10.1007/s00300-015-1885-7

Holtved, E. 1935-37. Erik Holtveds dagbog fra Thule Distriktet, 1935-1937. Unpubl. diary. Copenhagen: The Library of the Ethnographic Collections, The National Museum of Denmark.

- 1944. Archaeological investigations in the Thule District, I and II. Meddelelser om Grønland 141(1-2). Copenhagen: Kommissionen for Videnskabelige Undersøgelser i Grønland.

- 1967. Contributions to Polar Eskimo Ethnography. Meddelelser om Grønland 182(2). Copenhagen: Kommissionen for Videnskabelige Undersøgelser i Grønland.
Johansen, T.B. 2013. Foraging efficiency and small game: The importance of dovekie (Alle alle) in Inughuit subsistence. Anthropozoologica 48(1):75-88. http://dx.doi.org/10.5252/az2013n1a4

Malaurie, J. 1976. Les derniers rois de Thule: Avec les Esquimaux polaires face a leur destin. Paris: Plon.

Peary, R.E. 1898. Northward over the "Great Ice": A narrative of life and work among the shores and upon the interior ice-cap of northern Greenland in the years 1886 and $1891-1897$. New York: Frederick A. Stokes Co.

Rasmussen, K. 1919. Grønland langs Polhavet [Greenland along the Polar Sea]. København og Kristiania: Gyldendalske Boghandel.

- 1921. Thule Distriktet. Meddelelser om Grønland 60:517-567. Copenhagen: Kommissionen for Videnskabelige Undersøgelser i Grønland.

Ross, J. 1819. A voyage of discovery, made under the orders of the Admiralty, in His Majesty's Ships Isabella and Alexander, for the purpose of exploring Baffin's Bay, and inquiring into the probability of a North-West passage. London: J. Murray.

Sandell, H.T., and Sandell, B. 1991. Archaeology and environment in the Scoresby Sund Fjord: Ethno-archaeological investigations of the last Thule Culture of Northeast Greenland. Meddelelser om Grønland, Man \& Society 15. Copenhagen.

Schledermann, P. 1980. Polynyas and prehistoric settlement patterns. Arctic 33(2):292-302.

http://dx.doi.org/10.14430/arctic2562

- 1990. Crossroads to Greenland: 3000 years of prehistory in the eastern High Arctic. Komatik Series No. 2. Calgary, Alberta: The Arctic Institute of North America, University of Calgary.

- 1996. Voices in stone: A personal journey into the Arctic past. Komatik Series No. 5. Calgary, Alberta: The Arctic Institute of North America, University of Calgary.

—. 2003. The Muskox Patrol: High Arctic sovereignty revisited. Arctic 56(1):101 - 106.

http://dx.doi.org/10.14430/arctic606

Sørensen, M. 2010. Inuit landscape use and responses to climate change in the Wollaston Forland - Clavering $\varnothing$ region, Northeast Greenland. Geografisk Tidsskrift_Danish Journal of Geography 110(2):155-174.

http://dx.doi.org/10.1080/00167223.2010.10669505

Vibe, C. 1948. Langthen og Nordpaa. Copenhagen: Gyldendal.

- 1950. The marine mammals and the marine fauna in the Thule District (Northwest Greenland) with observations on ice conditions in 1939-41. Meddelelser om Grønland 150(6). Copenhagen: Kommissionen for Videnskabelige Undersøgelser i Grønland. 